\title{
Yabancı, Azınlık ve Milletlerarası Okullar Denetim Rehberinin Yasal Belgeler ve Alanyazın Temelinde Incelenmesi
}

\author{
Prof. Dr. Erdal Toprakçı \\ Ege Üniversitesi-Türkiye \\ erdal.toprakci@ege.edu.tr
}

Dilşad Bakur (Dok.öğr.)

Milli Eğitim Bakanlığı-Türkiye

dilsadbakir@hotmail.com

\section{Özet:}

Bu araştırmanın amacı "Yabancı, Azınlık ve Milletlerarası Okullar Denetim Rehberini" yasal belgeler ile alanyazın temelinde incelemektir. Araştırmada nitel araștırma temelinde doküman inceleme yöntemi kullanılmıştır. Veriler, içerik analizine tabi tutulmuştur. Araştırmanın sonuçlarına göre; rehberin yasal belgelerle çoğunlukla tutarlı olduğu fakat rehberde gönderme yapılan yasal belgelerin bir kısmının güncel olmadığı ya da yürürlükten kaldırıldığı tespit edilmiştir. Bunun dışında, rehberdeki bazı ifadelerde ilgili yasal belgeye gönderme yapılmadığı ya da eksik gönderme yapıldığı; bazı ifadelerin yasal belgedeki haline göre eksik ifade edildiği ya da yasal dayanağının olmadığı; gönderme yapılan yasal belgelerin bir kısmına internet ortamında ulaşılamadığı gibi sonuçlar ortaya çıkmıştır. Ayrıca, rehberin alanyazınla genel olarak tutarlı olduğu fakat rehberdeki ifadelerin hiçbirinde alanyazına gönderme yapılmadığı ve alanyazına göre içeriğinde eksiklikler olduğu belirlenmiştir.

Keywords: Denetim rehberi, Yabancı okullar, Azınlık okulları, Milletlerarası okullar

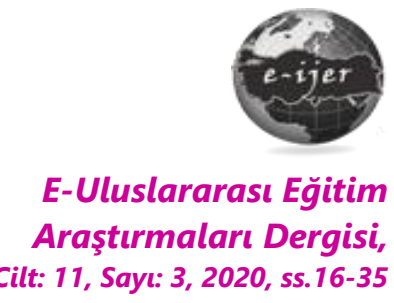

DOI: 10.19160/ijer.800326

\section{Önerilen Atıf}

Toprakçı, E. \&. Bakır, D. (2020). Yabancı, Azınlık ve Milletlerarası Okullar Denetim Rehberinin Yasal Belgeler ve Alanyazın Temelinde İncelenmesi, E-Uluslararası Eğitim Araştırmaları Dergisi, Cilt: 11, Sayı: 3, 2020, ss. 16-35, DOI: $10.19160 /$ ijer.800326 


\section{Giriş}

"Örgüt, iş ve işlev bölümü yapılarak, bir otorite ve sorumluluk hiyerarşisi içerisinde, ortak ve açık bir amacın gerçekleştirilmesi için bir grup insanın etkinliklerinin ussal eşgüdümüdür" (Schein 1978: 11). Her bir örgütün, farklı amaçları ve bunları gerçekleştirmek için tasarlanmış yapıları bulunmaktadır. Örgütsel yapının oluşumu, devamlılığı, güçlendirilmesi ve verimliliğinin sürekli kontrol edilebilmesi için etkili bir denetime ihtiyaç vardır. Denetim, örgütsel eylemlerin kabul edilen amaçlar doğrultusunda, saptanan ilke ve kurallara uygun olup olmadığının anlaşılma sürecidir (Aydın, 2014). Bir başka tanıma göre denetim, bütün devlet dairelerindeki görevlilerin kanunlar doğrultusunda görevlerini hakkıyla yapıp yapmadıklarını, görevlerini icra ederken ihmal ve dikkatsizlik gösterip göstermediklerini, suistimal edip etmediklerini tespit ederek haklarında gereken yasal işlemlerin yürütülmesi için devlet tarafından görevlendirilen müfettişler veya denetmenler vasıtasılla yapılan uygulamalardır (Taymaz, 2013). Denetim sistemi örgütsel ve yönetimsel bir zorunluluk olduğundan bütün örgütlerde yer almaktadır ve her formal örgüt varlığını sürdürmek için belli bir amacı veya amaçları gerçekleştirmek üzere kurulmaktadır (Aydın, 2014). Bu bağlamda birey, grup ya da topluma hizmet etmek için bir araya gelmiş sosyal sistemlerden biri de eğitim örgütleridir. Bütün örgütlerde olduğu gibi eğitim örgütlerinin de işlevlerini yerine getirebilmesi, kendini geliştirebilmesi ve güç kaybını önleyebilmesi için denetim gereklidir.

Eğitim denetimi, eğitimde gerçekleştirilen eylemlerin; mevcut yasal işleyişe, belirlenen amaca, hazırlanan plana, eldeki madde ve insan kaynaklarına uygun olup olmadığını kontrol etme sürecidir (Toprakçı, Çakırer, Bilbay, Bagcivan ve Bayraktutan, 2010: 15). Türkiye'de eğitimin denetimi Milli Eğitim Bakanlığı'nın (MEB) sorumluluğundadır. Milli Eğitim Bakanlığı eğitim denetimine ilişkin görev ve yetkisini 10.07.2018 tarih ve 30474 sayılı Cumhurbaşkanlığı Teşkilatı Hakkında Cumhurbaşkanlığı Kararnamesi'ne göre yürütmektedir. Söz konusu kararnamenin 301. maddesine göre MEB'in görev ve yetkileri "Okul öncesi, ilk ve orta öğretim çağındaki öğrencileri bedenî, zihnî, ahlakî, manevî, sosyal ve kültürel nitelikler yönünden geliştiren ve insan haklarına dayalı toplum yapısının ve küresel düzeyde rekabet gücüne sahip ekonomik sistemin gerektirdiği bilgi ve becerilerle donatarak geleceğe hazırlayan eğitim ve öğretim programlarını tasarlamak, uygulamak, güncellemek; öğretmen ve öğrencilerin eğitim ve ögrretim hizmetlerini bu çerçevede yürütmek ve denetlemek..." şeklinde tanımlanmıştır (RG, 2018). 10.07.2018 tarih ve 30474 sayılı Cumhurbaşkanlığı Teşkilatı Hakkında Cumhurbaşkanlığı Kararnamesi'nin 320. Maddesi ve buna bağlı olarak MEB Teftiş Kurulu Yönetmeliği'nin 34. maddesine göre MEB, okul/kurum denetimlerini Bakanlık Maarif Müfettişleri vasıtasıyla yapmaktadır (MEB, 2017-a; RG 2018). Okul/Kurum denetimi, bir eğitim kurumunun amaçlarını gerçekleştirmede insan ve madde kaynaklarının sağlanma ve faydalanma durumunun gözlenmesi, kontrol edilmesi ve belli kriterlere göre değerlendirilmesidir (Demirtaş ve Güneş, 2002). Diğer bir deyişle, okul/kurum denetimi; okul ve kurumların eğitim-öğretim etkinlikleri ile yönetim çalışmalarının yürürlükteki yasal metinler çerçevesinde uygunluk ve verimlilik açısından durumunun saptanması, personelin iş başında yetiştirilmesi, eğitim hedef ve amaçlarına ulaşma düzeyinin tespit edilmesi amacıyla yapılan denetim etkinliklerinin bütünüdür (MEB, 2019-a).

Okullardaki kurum denetimleri, 20.08.2017 tarih ve 30160 sayılı MEB Teftiş Kurulu Yönetmeliğine göre Bakanlık Maarif Müfettişlerince gerçekleştirilmektedir (MEB, 2017-a. Maarif müfettişleri; kendilerine verilen yetki temelinde rehberlik, denetim, inceleme, soruşturma, ön inceleme, araştırma, izleme-değerlendirme ve diğer görevleri yerine getirmektedir. Bu kapsamda Maarif Müfettişlerinin görevlerini yerine getirirken yararlanmaları için Milli Eğitim Bakanlığı Teftiş Kurulu Başkanlığı tarafından "Denetim Rehberleri" hazırlanmıştır. Bu rehberlerin amacl; Milli Eğitim Bakanlığı'nı ilgilendiren konularda Bakanlık personeline, Bakanlığa bağlı okul ve kurumlarına, özel öğretim kurumlarına, gerçek ve tüzel kişiler ile gönüllü kuruluşlara uygulamalarında yol göstermek; hizmetlerin kontrol ve denetimini ilgili birimlerle iş birliği içinde yapmak; süreç ve sonuçlarını mevzuata, belirlenmiş amaç ve hedeflere, performans ölçütlerine ve kalite standartlarına göre analiz ederek sonuçları rapor hâlinde ilgili birimlere ve kişilere iletmek, 
eğitim-öğretimin kalitesini arttırmak, Maarif Müfettişleri Başkanlıkları arasında uygulama birliği ve standartlaşmayı sağlamaktır (MEB, 2016). "Milî̃ Eğitim Bakanlığı Teftiş Kurulu Başkanlığı Görev, Yetki, Sorumluluk ve Çalışma Esaslarına Dair Yönergenin" 25. maddesine göre, Rehberlik ve Denetim Daire Başkanlığının görevlerinden birinin "Bakanlık merkez, taşra ve yurtdışı teșkilatı ile okul, kurum ve personelin rehberlik ve denetimine iliskin esasların ve rehberlerin hazırlanması, uygulanması ve geliştirilmesine ilişkin iş ve işlemleri yürütmek" olduğu görülmektedir (MEB, 2017-b). Bu rehberlerden biri de Yabancı, Azınlık ve Milletlerarası okullarının (makale boyunca "okul", "okullar" bu tür okulları ifade edecektir) denetiminde kullanılmak üzere hazırlanmıştır (makale boyunca "denetim rehberi" ya da "rehber" bu okullar için hazırlanmış rehberi ifade edecektir).

8/2/2007 tarihli ve 5580 sayılı Özel Öğretim Kurumları Kanunu'na göre yabancı okullar, yabancılar tarafından açılmış özel okullardır. Azınlık okulları ise; Rum, Ermeni ve Musevî azınlıklar tarafından kurulmuş, Lozan Antlaşması ile güvence altına alınmış ve kendi azınlığına mensup Türkiye Cumhuriyeti uyruklu öğrencilerin devam ettiği okul öncesi eğitim, ilköğretim ve ortaöğretim özel okullarını ifade etmektedir (Resmi Gazete, 2007). "Yabancı okullar", bağlı bulundukları devletlere göre isim alan, bu devletlerin himayesi altında yaşayan ve çeşitli dönemlerde yabancı ülkeler tarafından Türk topraklarında açılmış okullar iken; "Azınlık okulları" Osmanlı toplumundaki gayr-i müslimlerin kendi toplumlarının eğitim ve öğretmen gereksinimlerini karşılamak ve din adamı yetiştirmek için açılan okullardır. Osmanlı devleti döneminde açılmış ve özellikle sosyo-ekonomik, sosyo- kültürel ve stratejik bölgelerde yoğunlaşmış olan Yabancı ve Azınlık okullarının, Müslüman okullara göre sayıca üstün olma durumu Cumhuriyet dönemine kadar sürmüştür. Günümüzde ise, Türk okullarına oranla oldukça az sayıdadırlar. Bu okullar çalışma şekilleri genel olarak birbirine benzemekte ve varlıklı kimseler ya da yabancı devletlerin yardımıyla faaliyetlerini devam ettirmektedirler (Ertuğrul, 1997). 8/2/2007 tarihli ve 5580 sayılı Özel Öğretim Kurumları Kanunu'na göre; Milletlerarası okullar ise yalnız yabancı uyruklu öğrencilerin devam edebilecekleri özel öğretim kurumlarını ifade etmektedir. Bu okullar, 4875 sayılı Doğrudan Yabancı Yatırımlar Kanunu çerçevesinde, yabancı uyruklu gerçek ve tüzel kişiler tarafından veya Türk vatandaşlarıyla ortaklık yolu ile Cumhurbaşkanının izniyle açılabilmektedir (Resmi Gazete, 2007). Sözü geçen okulların sayısının ülkemizde her geçen gün arttığı görülmektedir. Bu bağlamda en son yayınlanan 2019-2020 örgün eğitim istatistiklerine göre Türkiye'de şu anda 4 anaokulu, 23 ilkokul (bünyesinde ana sınıfı da olan), 21 ortaokul ve 11 ortaöğretim kurumu olmak üzere 59 "Azınlık okulu"; 1 ilkokul (bünyesinde ana sınıfı da yer alan) ve 11 ortaöğretim kurumu olmak üzere 12 "Yabancı okul"; 7 ilkokul, 62 ortaokul ve 63 ortaöğretim kurumu olmak üzere 132 "Milletlerarası okul" faaliyetlerini sürdürmektedir (MEB, 2020). Bu okullar da ilgili denetim rehberi kılavuzluğunda Milli Eğitim Bakanlığı maarif müfettişleri aracılığıyla denetlemektedir. Rehber, hem denetlenen kuruma hem de denetleyene yol gösteren bir belgedir. Bu belgenin görevini layıkıyla yerine getirebilmesi için de mümkün olan en az eksik ve hata barındıran nitelikte olması gerekir. Bunun için de bilimsel bir analize tabi tutmak adına özellikle eğitim denetimi alanyazını ve yasal belgeler temelli bir inceleme yararlı olabilir.

Bir denetim rehberi yasalara dayanmalıdır. Eğer dayanmazsa sorunlar çıkar. Öte yandan bilimsel bilgiye dayanması gerektiği de ortadadır. Bilimsel bilginin, yasaları etkileme ve belirleme işlevi bilimi kültür haline getirmiş toplumlarda yaygın olmakla birlikte ülkemizde bu kültürün var olduğunu söylemek pek de doğru gözükmemektedir. Bu temelde söz konusu okulların denetim rehberinde de bu özellik aranabilmelidir. Denetim rehberi bu özellik ile donatılmış olursa, nitelikli bir denetsel faaliyetin gerçekleşebileceği de ortadadır.

Alanyazın (eğitim denetimi) incelendiğinde "Yabancı ve Azınlık okullarının" denetimleri ile ilgili çok az sayıda çalışma tespit edilmiştir. Bunlardan biri, Osmanlı Devleti'nde yabancı okullardaki denetim ve Cumhuriyet dönemine yansımaları (Haydaroğlu, 2008) iken bir diğeri de devlet ve azınlık okullarının yönetimsel süreçler açısından karşılaştırmasıdır (Tilbe, 2016); diğer taraftan, "Milletlerarası okulların" denetimine ilişkin hiçbir çalışmaya rastlanmamıştır. Diğer 
yandan, alanyazında ülkemizdeki eğitim denetimine yönelik sorunların ele alındığı çalışmalara ulaşılmıştır (Kayıkçı ve Şarlak, 2013; Kayıkçı, 2016; Kayıkçı, Özyıldırım ve Özdemir, 2016). Ayrıca, yasal belgeleri temel alan yönetim ve denetimle ilgili çalışmaların yapıldığı da tespit edilmiştir. Bu çalışmalarda, Türkiye'deki bakanlıkların eğitim yönetimi ve denetimi alanındaki uygulamaları (Toprakçı ve Kadı, 2014); kamu yararına çalışan derneklerin eğitim faaliyetlerinin yönetimi ve denetimi (Toprakçı ve Akçay, 2016); Milli Eğitim Bakanlığı Sayıştay denetim raporları (Toprakçı ve Bakır, 2019); öğretmen teftiş formlarının (Kış, Konan ve Sönmez, 2011) ve yönetici teftiş formlarının değerlendirilmesi (Konan, Kış ve Demir: 2011); ilkokul ve ortaokul yöneticilerinin yönetici teftiş formuna ilişkin görüşleri (Konan ve Çoban, 2013); il eğitim denetmenlerinin yönetici teftiş formunda yer alan değerlendirme ölçütlerine ilişkin görüşleri (Konan ve Çoban, 2013); okul öncesi öğretmenlerinin öğretmen teftiş formundan aldıkları puanların analizi (Konan ve Oğuz, 2014) ve bu formdaki değerlendirme ölçütlerine ilişkin görüşleri (Konan ve Oğuz, 2015) ele alınmıştır. Fakat yukarıda değinilen Yabancı ve Azınlık okullarının denetimi ile ilgili iki çalışma dışında genel olarak denetimleri ve özel olarak da MEB tarafından hazırlanan Yabancı, Azınlık ve Milletlerarası okulların denetim rehberi ile ilgili bir çalışmaya rastlanmamıştır. Bu araştırma ile "Yabancı, Azınlık ve Milletlerarası Okullar Denetim Rehberi" yasal belgeler ve alanyazın temelinde incelenmiş ve elde edilen sonuçlar üzerinden gerek uygulayııılara gerekse araştırmacılara önerilerde bulunulmuştur.

\section{YÖNTEM}

\section{Araştırmanın modeli:}

Araştırmanın problemine uygun olarak nitel araştırma temelinde doküman inceleme yöntemi kullanılmıştır. Nitel araştırma, önceden bilinen veya fark edilmemiş problemlerin algılanmasına ve probleme yönelik doğal olguların gerçekçi bir şekilde ele alınmasına ilişkin öznel-yorumlayıcı bir süreci temel almaktadır (Seale, 1999). Doküman inceleme ise araştırmada incelenen olgu veya olaylarla ilgili bilgiler içeren yazılı belgelerin ayrıntılı olarak taranması ve bu bilgilerden yeni bir bütünlük oluşturulması şeklinde ifade edilir (Creswell, 2002). Doküman incelemesi kişisel dokümanlarda olduğu gibi kamu ve arşiv dokümanlarında da kullanılabilir. Denetim rehberleri, MEB Teftiş Kurulu Başkanlığı'nın denetimde uygulama birliğini sağlamak amacıyla kullandığı kamu belgeleri olarak doküman incelemesine uygun kaynaklar olduğundan bu araştırmada doküman incelemesinin aşamalarına göre bir yol izlenmiştir.

\section{Çalışma dokümanı:}

MEB Teftiş Kurulu Başkanlığı, 2016 yılında çeşitli kurumların teftişine yönelik olarak hazırlanan 16 adet denetim rehberi yayımlamıştır. Bu rehberler maarif müfettişlerinin teftiş sürecinde uygulayacakları esasları içermektedir. Çalışma dokümanı; yayımlanan rehberler arasında yer alan "Yabancı, Azınlık ve Milletlerarası Okullar Denetim Rehberi'dir". Söz konusu belgeye, MEB Teftiş Kurulu Başkanlığı́nın internet sitesinin "Yayımlarımız" sayfasından 24.04.2020 tarihinde ulaşılmıştır. Diğer yandan yasal ve alanyazın belgelerine ulaşmak ile ilgili olarak ise çevrim içi ortam (Google Akademik, Mevzuat - resmi siteleri, Google ve Yandex'de anahtar kavram bazlı tarama) ile araştırmacıların gerçek ve sanal kütüphanesinde bulunan kaynaklardan yararlanılmıştır. Buna göre ulaşılan belgeler (rehber hariç olmak üzere) sınırlığında bir incelemenin gerçekleştirildiğini belirtmek gerekir. 


\section{Verilerin Toplanması ve Analizi:}

Doküman incelemesi tekniğinin uygulanması beş aşamadan oluşmaktadır: Dokümanlara ulaşma, dokümanların orijinalliğini kontrol etme, dokümanları anlama, veriyi analiz etme ve kullanma (Forster, 1995: Akt. Yıldırım ve Şimşek, 2013). Dokümanlara ulaşma aşamasında "Yabancı, Azınlık ve Milletlerarası Okullar Denetim Rehberine" Milli Eğitim Bakanlığı Teftiş Kurulu Başkanlığı'nın resmi internet sitesinden; ardından rehberde bahsi geçen ilgili kanun, yönetmelik, yönerge, genelge ve diğer belgelere yine bakanlığın kendi sitesinden ulaşılmıştır ve orijinalliği (gerek uzmanlar gerekse diğer çevrimiçi olanaklar bağlamında) teyit edilmiştir. Dokümanları anlama aşamasında öncelikle ilgili rehber ardından rehberde bahsi geçen mevzuat detaylı olarak incelenmiştir.

Veriler, içerik analizine tabi tutulmuştur. Iç̧erik analizinde temelde yapılan işlem, birbirine benzeyen verileri belirli kavramlar ve temalar çerçevesinde bir araya getirmek ve bunları okuyucunun anlayabileceği bir biçimde düzenleyerek yorumlamaktır (Yıldırım ve Şimşek, 2013: 259). İçerik analizi; verilerin kodlanması, temaların bulunması, kodların ve temaların düzenlenmesi, bulguların tanımlanması ve yorumlanması aşamalarından oluşmaktadır (Yıldırım ve Şimşek, 2013). Bundan dolayı verilerin analizi aşamasında söz konusu rehberin öncelikle gönderme yaptığı yasal belgelerle sonrasında ise alanyazınla ilişkisinin analizi yapılmıştır. Bunun için araştırmacılar rehberi, çevrim içi ortamdan edindikleri kaynakları, kendi gerçek ve sanal kütüphanelerindeki kaynakları "alanyazınsal zihin çerçeveleri" sınırılığında yeterli düzeye gelene kadar inceleyerek kod, kategori ve temalara ulaşmışlardır. Buna göre tersinden ifade etmek gerekirse; bir denetim rehberinin yasa ve alanyazın ile olan ilişkisi temalar olarak biçimlenirken, yasal belgeler ve alanyazın ile ilişkisinde tutarlılık ve tutarsızlık şeklinde kategoriler, ayrı ayrı olmak üzere onların altında da "Yasal dayanağa uygunluk", "Yasal dayanağa göre güncel olmama", "Yasal dayanak belirsizliği", "ilgili yasal dayanaklara eksik gönderme", "Yasal boşluk", "Yasal dayanağa internet ortamında ulaşamama", "Yasal dayanağa göre eksik ifade edilme", "Yasal dayanağın hatalı ifade edilmesi", "Yasal dayanağa göre fazla ifade edilme", "Karşılksız", "Uygunluk", "içerik eksikliği", "Atıfsızlık", "Kavram tutarsızlığı" ve "Aykırılık" şeklinde kodlar ortaya çıkmıştır. Verilerin bulguya dönüşmesinde anlaşılmayı kuvvetlendirmek verilerin yüzde dağılımı ya da sayısallaştırma yoluna da gidilmiştir. Son olarak veriyi kullanma aşamasında belirlenen temalara göre uygun olan alıntılarla analiz desteklenmiş ve yorumlanmıştır. Yapılan içerik analizine birkaç örnek Tablo 1'de verilmiştir.

Rehberdeki bazı ifadeler; gerek içerik yönünden detaylı olması, gerek gönderme yapılan yasal belgenin ilgili maddesinin kapsamının geniş olması nedeniyle birden fazla temayla ilişkili çıktığı için her temanın altında ayrı ayrı değerlendirilmiştir. Bu durum göz önünde tutularak ilgili madde sayısallaştırma yapıırken ilişkili olduğu her temada yeniden kullanıımıştır. Örneğin rehberin "Yönetim Faaliyetleri" bölümünün "Öğrenci İşleri" alt başlığında yer alan "Belge, defter, çizelge, sözleşme ve formlardan gerekenlerin çıtılarının alınarak okul müdürünce onaylanması ve saklanmasl; veri girişinde yapılan yanlışlıların usulünce düzeltilmesi (Ortaöğretim Kurumları Yönetmeliği Md. 76, 221; Talim Terbiye Kurulu Başkanlığı çıkışlı basılı evrak örnekleri)" ifadesi incelendiğinde söz konusu ifadenin ilgili yönetmelikteki karşılığıyla uyumlu olduğu görülmüştür. Bu nedenle ilgili ifade "Denetim rehberinin yasal belgelerle ilişkisi temasını"," "Yasal belgelerle tutarlı̆̆ı kategorisinin" ve son olarak "Yasal dayanağa uygunluk" kodu kapsamında ele alınmıştır. Diğer yandan ifadede geçen Talim Terbiye Kurulu Başkanlığı çıkışlı basılı evrak örneklerine ulaşılamadığından ya da ilgili evrakların ekleri bulunamadığından aynı ifade "Denetim rehberinin yasal belgelerle ilişkisi temasının", "Yasal belgelerle tutarlıı̆ı kategorisinin" ve son olarak "Yasal dayanağa internet ortamında ulaşamama" koduna da dahil edilmiştir. 
Tablo 1 içerik Analizi Örnekleri

\begin{tabular}{|c|c|c|c|}
\hline $\begin{array}{l}\text { Te } \\
\text { m } \\
\text { al } \\
\text { ar }\end{array}$ & $\begin{array}{c}\text { Kate } \\
\text { goril } \\
\text { er }\end{array}$ & $\begin{array}{l}\text { Ko } \\
\text { dl } \\
\text { ar }\end{array}$ & Kodları biçimleyen ifadeler \& Gönderme yapılan yasal belge/ ilgili madde \\
\hline \multirow{4}{*}{ 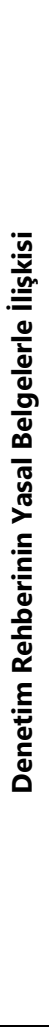 } & \multirow{2}{*}{ 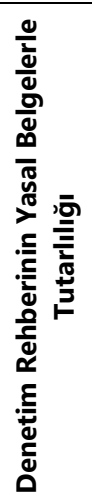 } & 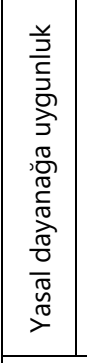 & $\begin{array}{l}\text { Rehberde: } \\
\text { Eğitim- Öğretim Faaliyetleri bölümünün "Eğitim-Öğretim Ortamları" alt başlığında yer alan ifade: Atatürk } \\
\text { köşesinin düzenlenmesi; oda ve dersliklere Atatürk fotoğrafı, İstiklâl Marşı ve Gençliğe Hitabe levhalarının uygun } \\
\text { şekilde yerleştirilmesi (Millı́ Eğitim Bakanlığı Kurum Tanıtım Yönetmeliği) } \\
\text { Yasal belgedeki karşılığı: } \\
\text { MADDE } 8 \text { - (1) Her tür kurumda kullanılan; Atatürk Posteri tablosunda, Atatürk fotoğrafının altında "Mustafa } \\
\text { Kemal Atatürk" yazısı ve "1881-1938" tarihleri yer alır. } \\
\text { (2) Istiklal Marşı tablosunda, metnin üst tarafında dalgalanan Türk Bayrağı bulunur. Amblemde yer alan meşale } \\
\text { alevi metnin üzerinde filigran olarak yer alır. } \\
\text { (3) Gençliğe Hitabe tablosunda metnin üst tarafında Atatürk resmî bulunur. Amblemde yer alan meşale alevi } \\
\text { metnin üzerinde filigran olarak yer alır. }\end{array}$ \\
\hline & & \multicolumn{2}{|r|}{$\begin{array}{l}\text { Rehberdeki "Atatürk köşesinin düzenlenmesi; oda ve dersliklere Atatürk fotoğrafı, Istiklâl Marşı ve Gençliğe Hitabe } \\
\text { levhalarının uygun şekilde yerleştirilmesi" ifadesi incelendiğinde MEB Kurum Tanıtım Yönetmeliğine gönderme } \\
\text { yapıldığı görülmektedir. Ilgili yönetmelik incelendiğinde rehberdeki ifadenin yasal dayanakla doğru ilişkilendirildiği } \\
\text { tespit edildiğinden bu kod tercih edilmiştir. }\end{array}$} \\
\hline & 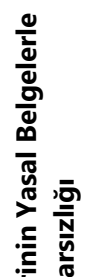 & 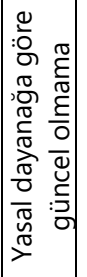 & $\begin{array}{l}\text { Rehberde: } \\
\text { Eğitim- Öğretim Faaliyetleri bölümünün "Eğitim-Öğretim Ortamları" alt başlığında yer alan ifade: Yatılı öğrenci } \\
\text { sayısının kontenjana uygun olması (MEB'e Bağlı Okul Pansiyonları Yönetmeliği Md.7) } \\
\text { Yasal belgedeki karşılığı: } \\
\text { 25/11/2016 tarihli ve } 29899 \text { sayılı "Millî Eğitim Bakanlığına Bağlı Resmî Okullarda Yatılılık, Bursluluk, Sosyal } \\
\text { Yardımlar ve Okul Pansiyonları Yönetmeliği'nin" 9. ve 10. maddesi. }\end{array}$ \\
\hline & 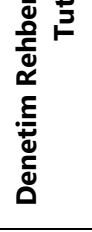 & \multicolumn{2}{|r|}{$\begin{array}{l}\text { Rehberdeki "Yatılı öğrenci sayısının kontenjana uygun olması" ifadesi incelendiğinde MEB'e Bağlı Okul Pansiyonları } \\
\text { Yönetmeliği'nin } 7 \text {. Maddesine gönderme yapıldığı görülmektedir. Oysa gönderme yapılan yönetmelik eskidir. } \\
\text { 15/8/1983 tarihli ve } 83 / 9650 \text { sayılı Bakanlar Kurulu Kararı ile yürürlüğe konulan "Millî Eğitim Bakanlığına Bağlı Okul } \\
\text { Pansiyonları Yönetmeliği" hükümleri sadeleştirilerek "Millî Eğitim Bakanlığına Bağlı Resmî Okullarda Yatıılık, Bursluluk, } \\
\text { Sosyal Yardımlar ve Okul Pansiyonları Yönetmeliği" adıyla 25/11/2016 tarihli ve } 29899 \text { sayılı Resmî Gazete'de } \\
\text { yayımlanarak yürürlüğe konulmuştur. Buna göre ilgili ifade güncellenen yönetmeliğin 9. ve 10. maddesinde } \\
\text { geçmektedir. }\end{array}$} \\
\hline \multirow{4}{*}{ 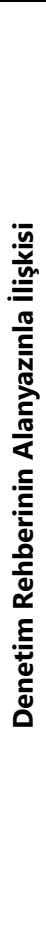 } & \multirow[t]{2}{*}{ 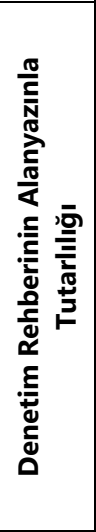 } & $\begin{array}{l}\frac{y}{3} \\
\text { I } \\
\text { פ } \\
\text { ป }\end{array}$ & $\begin{array}{l}\text { Rehberde: } \\
\text { "İzleme ve Değerlendirme" bölümünde geçen ifade: Rehberlik ve denetimi yapılan kurumun raporunda yer alan } \\
\text { tespit ve önerilerin uygulanmasına ilişkin olarak, denetlenen birimce hazırlanan "Gelişim Planı" çerçevesinde } \\
\text { yürütülen çalışmalar ve düzeyi değerlendirilecek, gelişim planı ile ilgili varsa sorunlar ve çözüm önerilerine yer } \\
\text { verilecektir. } \\
\text { Alanyazında: } \\
\text { Etkili okul gelişim planlarının oluşturulması sürecinde yapılan eylemleri ve dikkat edilen hususları şu şekilde } \\
\text { sıralamak mümkündür (MacGilchrist ve Mortimore, 1997: 201): } \\
\text { - Personelin çoğunluğu ve okul müdürü, kurum için belirlenen açık bir hedef hakkında hemfikir olabilmelidir. } \\
\text { - Mevcut stratejilerin ve zayıf noktaların sistematik denetimini yapmak önemlidir. } \\
\text { - Değişim planı derinlemesine her açıdan düşünülmektedir. } \\
\text { - Kurum dışında bir temsilcinin (acentenin) olması gerekmektedir. } \\
\text { • Değişim planının uygulanması, kurum dışındaki yetkililer tarafından desteklenmektedir. } \\
\text { - İlerlemenin değerlendirilmesi biçimlendirici olarak, uygulamaların desteklenmesi için kullanılmaktadır. }\end{array}$ \\
\hline & & \multicolumn{2}{|r|}{$\begin{array}{l}\text { Rehberde gelişim planı çerçevesinde yapılan çalışmaların değerlendirilmesinden bahsetmiştir. Gelişim planlarının } \\
\text { hazırlanmasının gerekliliği alanyazında da geçmektedir. }\end{array}$} \\
\hline & \multirow[t]{2}{*}{ 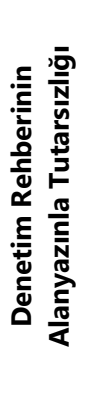 } & 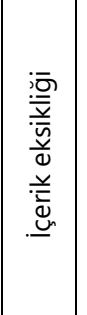 & $\begin{array}{l}\text { Rehberde: } \\
\text { Amaç: Millî Eğitim Bakanlığına bağlı yabancı, azınlık ve milletlerarası okulların denetiminde uygulanacak esasları } \\
\text { belirlemektir. } \\
\text { Alanyazında: } \\
\text { Turner' (1970) göre, "denetimin amacı, öğrenme sürecinin iyileştirilmesi, öğretim programının, öğrenme ve } \\
\text { öğretme materyallerinin geliştirilmesidir. Hizmet-içi eğitimin yerleşmesine ön ayak olmak; öğretmenlere ihtiyaç } \\
\text { duydukları her türlü yardımı vermek; öğretmenlere, kendilerinin ve eğitim hizmeti yapanların rollerini } \\
\text { tanımlamalarında yardım etmek; uzmanlar arasındaki eşgüdümü işler hale getirmek de denetimin amaçları } \\
\text { arasındadır." }\end{array}$ \\
\hline & & \multicolumn{2}{|r|}{$\begin{array}{l}\text { Rehberde yabancı, azınlık ve milletlerarası okulların denetiminde uygulanacak esasların amacından bahsederken } \\
\text { alanyazın içeriği bağlamlı bir eksiklik olduğu göze çarpmaktadır. Bu da "içerik eksikliği" kodu olarak biçimlenmiştir. }\end{array}$} \\
\hline
\end{tabular}

\section{Geçerlik ve Güvenirlik:}

Çalışmanın geçerliliğini ve güvenilirliğini sağlamak için çeşitli teknikler kullanılmıştır. Uzman incelemesi ve meslektaş teyidi ile verilerin iç geçerliliği (inandırıcılık) sağlanmıştır. 
Meslektaş teyidi; verilerin karşılaştıılarak uyumunun ortaya çıkarılmasını hedefler. Uzman incelemesi ise araştırma sürecine eleştirel gözle bakan ve araştırmacıya geribildirimde bulunan uzman görüşünü belirtmektedir (Creswell, 2003; Yıldırım ve Şimşek, 2013). Araştırmanın geçerliğinin sağlanması için ilk olarak meslektaş teyidine gidilmiştir. Bunun için MEB Teftiş Kurulu Başkanlığı́nın farklı kurumlara yönelik denetim rehberlerini inceleyen araştırmacılar düzenli aralıklarla her hafta belirlenen gün ve saatte internet ortamında canlı toplantı araçları üzerinden bir araya gelmiştir. Tekrar izlenebilmesi için bu toplantılar kaydedilmiştir. Toplantılarda rehberlerin hangi yönlerden incelenebileceğine ilişkin tartışmalar yapılmıştır. Sonrasında ise araştırmacılar inceledikleri rehberlere yönelik içerik analizi yaparak kodlar ve temalar oluşturmuş ve bunların benzer ve farklı yönleri üzerinde durmuştur. Anlaşmazlığa düşülen noktalar değerlendirilmiş ve fikir birliğine varıncaya kadar toplantılar devam etmiştir. Denetim Rehberinde geçen "brifing dosyalarının hazırlanması" ifadesi çözüme kavuşturulan anlaşmazlıklardan birine örnek olarak verilebilir. Araştırmacı tarafından bu ifadeye yönelik hiçbir yasal dayanağa ulaşılamadığından bu ifade "Yasal boşluk" koduyla ilişkilendirilmiştir. Online toplantılar sırasında bu ifadenin 1442 sayılı Tebliğler Dergisi'nde yer aldığı dile getirilmiş, bundan dolayı söz konusu kodla ilişkilendirilemeyeceği belirtilmiştir. IIlgili yasal dayanağa ulaşıldığında bunun brifing verilmesine yönelik bir ifade olduğu, brifing dosyasının ise farklı bir kavram olarak rehberde yer aldığı sonucuna ulaşılmıştır. Ayrıca uzman görüşü için denetim alanında yetkin ve yayımları olan bir akademisyen ile bir maarif müfettişi bu toplantılarda yer alarak toplantı sürecinde geribildirimlerde bulunmuşlardır. Geçerlik ve güvenirliğin sağlanması için değerlendirilen rehberlerin görüş birliğine dayalı olarak analiz edilmesine ve ayrıntılı raporlaştııımasına dikkat edilmiştir. Son toplantının ardından çalışma alanında uzman akademisyenlere gönderilmiş ve onların görüşleri de çalışmaya dahil edilmiştir. Diğer araştırmacıların talebi olursa veya gelecekte başka bir araştırmada karşılaştırma yapılması gerekirse diye araştırmanın ham verileri saklanmıştır böylece dış güvenilirlik (teyit edilebilirlik) arttırılmaya çalışımıştır.

\section{BULGULAR VE YORUM}

Bu bölümde "Yabancı, Azınlık ve Milletlerarası Okullar Denetim Rehberinin" yasal belgeler ile alanyazın temelinde analiz edilmesi sonucu ortaya çıkan temaların ve kodların dağılımına, bulguları destekleyen alıntılara ve bu bulguların yorumlanmasına yer verilmiştir. Rehbere ilişkin yapılmış bir çalışmaya rastlanmadığı için bulgular, alanyazındaki çalışmaların benzer ve farklı yönleri açısından karşılaştırılarak yorumlanamamıştır.

\section{1- Denetim Rehberinin Yasal Belgelerle İlişkisi}

Aşağıda yer alan Tablo 2'de "Denetim rehberinin yasal belgelerle ilişkisi teması" altında "Denetim rehberinin yasal belgelerle tutarlıı̆ı" ve "Denetim rehberinin yasal belgelerle tutarsızlı̆ı" kategorileri ve kodlarının dağılımları gösterilmiştir.

Tablo 2 "Denetim rehberinin yasal belgelerle ilişkisi" teması altında ortaya çıkan kategori ve kodların dağılımı

\begin{tabular}{|c|c|c|c|}
\hline Tema & Kategoriler & Kodlar & $\mathbf{f}$ \\
\hline \multirow{11}{*}{ 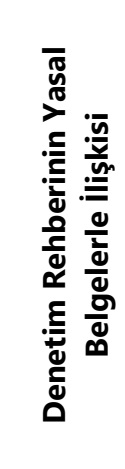 } & $\begin{array}{l}\text { 1. Denetim Rehberinin } \\
\text { Yasal Belgelerle Tutarlılığı }\end{array}$ & Yasal dayanağa uygunluk & 114 \\
\hline & & Yasal dayanağa göre güncel olmama & 37 \\
\hline & & Yasal dayanak belirsizliği & 36 \\
\hline & & İlgili yasal dayanaklara eksik gönderme & 20 \\
\hline & & Yasal boşluk & 6 \\
\hline & 2. Denetim Rehberinin & Yasal dayanağa internet ortamında ulaşamama & 6 \\
\hline & Yasal Belgelerle Tutarsızlığı & Yasal dayanağa göre eksik ifade edilme & 5 \\
\hline & & Yasal dayanağın hatalı ifade edilmesi & 3 \\
\hline & & Yasal dayanağa göre fazla ifade edilme & 1 \\
\hline & & Karşılıksız & 1 \\
\hline & & Toplam & 115 \\
\hline
\end{tabular}


Tablo 2 incelendiğinde "Denetim rehberinin yasal belgelerle tutarlıı̆ı" ve "Denetim rehberinin yasal belgelerle tutarsızlığı" olmak üzere iki temanın ön plana çıkığı görülmektedir. Ayrıca, Tablo 2'de de belirtildiği gibi, "Denetim rehberinin yasal belgelerle tutarllığı $(n=114)$ " kategorisi altında "Yasal dayanağa uygunluk" kodu; "Denetim rehberinin yasal belgelerle tutarsızlığı $(n=115)$ " kategorisi altında "Yasal dayanağa göre güncel olmama", "Yasal dayanak belirsizliği", "ilgili yasal dayanaklara eksik gönderme", "Yasal boşluk", "Yasal dayanağa internet ortamında ulaşamama", "Yasal dayanağa göre eksik ifade edilme", "Yasal dayanağın hatalı ifade edilmesi", "Yasal dayanağa göre fazla ifade edilme" ve "Karşllısız" kodları tespit edilmiştir.

\subsection{Denetim Rehberinin Yasal Belgelerle Tutarlılı̆̆}

"Denetim rehberinin yasal belgelerle tutarlı̆̆ı $(n=114)$ " kategorisi altında "Yasal dayanağa uygunluk" olarak bir tane kod tespit edilmiştir. "Denetim rehberinin yasal belgelerle tutarlıı̆ının" "Yasal dayanağa uygunluk" kodu, rehberdeki kısım ile yasal belgeye ilişkin gönderme örtüşüyorsa veya ikisi birbiriyle doğru şekilde ilişkilendirilmişse tercih edilmiştir. Rehberin giriş bölümünde yer alan "Yabancı, azınlık ve milletler arası okulların rehberlik ve denetimlerinde; 'Özel mevzuatı bulunan okul veya kurumlarda öncelikle özel mevzuat hükümleri doğrultusunda işlem yapılır.' hükmü gereği öncelikle Milli Eğitim Bakanlı̆ının onayı ile yürürlükte olan özel mevzuatına göre işlem yapılmalıdır (Özel Öğretim Kurumları Yönetmeliği Md. 49)" ifadesi ile ifadenin yanında atıf yapılan ilgili yönetmelik maddesinin ilişkisine bakılmıştır. İlgili yönetmeliğin 49. maddesi ise şu şekildedir: "Kurumlarda öğretim dili Türkçedir. Yabancılar tarafından açılmış ve Türkçeden başka bir dille ögretim yapılmasına izin verilmiş bulunan mevcut okullar, kendi statüleri içinde öğretime devam ederler. Ancak, yabancı uyruklu çocukların devam edeceği milletlerarası okullar bu hükmün dışındadır. (2) (Ek:RG-5/7/2014-29051 Özel okullarda (Değişik ibare:RG19/2/2020-31044) Cumhurbaşkanı kararıla tespit edilen Türk vatandaşlarının günlük yaşamlarında geleneksel olarak kullandıkları farklı dil ve lehçelerde eğitim ve ögrretim yapılabilir. Bu okullarda: a) Farklı dil ve lehçelerde okutulacak dersler Bakanlıkça belirlenir. b) Okulun seviyesine göre Bakanlıkça onaylanan dersler ve öğretim programları ile haftalık ders dağıtım çizelgeleri uygulanır." Görüldüğü üzere, rehberdeki kısım ile gönderme yapılan yasal belgenin ilgili maddesi doğru bir şekilde ilişkilendirildiğinden bu ifade "Denetim rehberinin yasal belgelerle tutarlıı̆ı" kategorisinin "Yasal dayanağa uygunluk $(n=114)$ " kodu altında incelenmiştir. Bu koda ilişkin ifadelerin çok çıkmış olması, denetim rehberinin yasal belgelerle ilişkisinin tutarlıık temelinde (tutarsızlıkla neredeyse aynı oran) yarı yarıya da olsa olumlu olduğunu söylemeye cesaretlendirebilir. Bu durum rehberin hazırlandığı tarihte gönderme yapılan yasal belgelerin güncelliğini koruması ile açıklanabilir. Diğer yandan rehberin niteliği ile ilgili olarak da bir olumluluktan söz edilmesine katkı sağlayabilir.

\subsection{Denetim Rehberinin Yasal Belgelerle Tutarsızlı̆gı}

"Denetim rehberinin yasal belgelerle tutarsızlığ $(n=115)$ " kategorisinin kodları incelendiğinde "Yasal dayanağa göre güncel olmama $(n=37)$ ", "Yasal dayanak belirsizliği $(n=36)$ " ve "ilgili yasal dayanaklara eksik gönderme $(n=20)$ " kodlarında en çok ifadeye rastlanmıştır.

"Yasal dayanağa göre güncel olmama $(n=37)$ " kodu rehberdeki ifadenin ya da bu ifadenin yanında yer alan yasal belgenin güncel olmadığı ya da yürürlükten kaldııılığı durumda tercih edilmiştir. Rehberdeki "Yönetim Faaliyetleri" bölümünün "Örgütleme" alt başlığında yer alan ifade bu kod kapsamında örnek gösterilebilir: "Kaynaştırma yoluyla eğitim yapılan okullarda, Bireyselleştirilmiş Eğitim Programı Geliştirme Biriminin çalışmalarının değerlendirilmesi (Özel Eğitim Hizmetleri Yönetmeliği Md. 72, 73, 74; MEB Özel Eğitim ve Rehberlik Hizmetleri Genel Müdürlüğünün 02/09/2008 tarih ve 2008/60 sayılı "Kaynaştırma Yoluyla Eğitim Uygulamaları konulu Genelgesi Md. 3)." Denetim rehberinden yapılan bu alıntı incelendiğinde 31/05/2006 tarihli ve 26184 sayılı Özel Eğitim Hizmetleri Yönetmeliğinin yürürlükten kaldııılığı ve rehberde eski yönetmelikteki maddelere gönderme yapıldığı tespit edilmiştir. Bu bağlamda, güncellenen Özel Eğitim Hizmetleri Yönetmeliği'nin 47. ve 48. maddesine gönderme yapılması gerekirdi. 
Buna ek olarak, MEB Özel Eğitim ve Rehberlik Hizmetleri Genel Müdürlüğünün 02/09/2008 tarih ve 2008/60 sayılı "Kaynaştırma Yoluyla Eğitim Uygulamaları" konulu Genelgesi'nin de yürürlükten kaldırıldığı ve 19/09/2017 tarihinde "Kaynaştırma/Bütünleştirme Yoluyla Eğitim Uygulamaları Genelgesi'nin" yürürlüğe girdiği belirlenmiștir. Söz konusu koda ilişkin ifadelerin oldukça fazla sayıda göze çarpmasının nedeninin rehberin 2016 yılında hazırlanması ve sonrasında güncellenmemesi olabilir.

"Yasal dayanak belirsizliği $(n=36)$ " kodu ise rehberde ilgili konuya ilişkin yasal belgeye açıç̧a gönderme yapılmadığı durumlar tespit edildiğinde kullanılmıştır. Bu doğrultuda, bu koda rehberin "Eğitim-Öğretim Faaliyetleri" bölümünün "Eğitim-Öğretim Faaliyetlerinin Sonuçları" alt başlı̆ında yer alan "devam-devamsızlık, disiplin, sınıf tekrarı, okuldan ayrılma (terk), ödül (teşekkür, takdir, iftihar belgesi), sosyal etkinliklere katılım, yatılılı ve bursluluk, rehberlik ve danışma hizmetlerinden yararlanma durumuna (eğitsel, mesleki, bireysel)" ilişkin ifade örnek gösterilebilir. Görüldüğü üzere ilgili ifadenin ilişkili olduğu yasal belgeye ilişkin hiçbir gönderme yapılmamıştır. Oysa bu ifadelere yönelik birçok yasal belge bulunmaktadır. MEB Ortaöğretim Kurumları Yönetmeliği'nin "Geç gelme, devamsızlık ve ilişik kesme (Madde 35-36)", "Disiplin (Madde 163-175)", "Sınıf tekrarı ve öğrenim hakkı (Madde 59)", "Ödül (Madde 159-162)", "Sosyal etkinliklere katılım (Madde 157/ 3, 7c)" gibi bazı bölümleri bu ifadelerin yasal dayanağını oluşturmaktadır. Buna ek olarak, sosyal etkinliklere katılım ile ilgili hususlar için MEB Eğitim Kurumları Sosyal Etkinlikler Yönetmeliği'nden; yatılılık ve bursluluk ile ilgili yasal belge olarak MEB'e Bağlı Resmî Okullarda Yatılılık, Bursluluk, Sosyal Yardımlar ve Okul Pansiyonları Yönetmeliği'nden; rehberlik ve danışma hizmetlerinden yararlanmaya yönelik yasal dayanak için ise Rehberlik ve Psikolojik Danışma Hizmetleri Yönetmeliği'nden de destek alınabileceği anlaşılmıştır. Bu kodla ilişkili ifadelerin çok çıkması rehber hazırlanırken kapsamlı bir çalışma yapılmamasından kaynaklı olabilir. Diğer yandan bu durumun rehberin niteliğini olumsuzlaştırıcı bir etkide bulunduğundan da söz edilebilir.

"Ilgili yasal dayanaklara eksik gönderme $(n=20)$ " kodu; rehberde gönderme yapılan ilgili belgede başka maddelere de atıf yapılması gerekiyorsa, araştırmalar esnasında gönderme yapılan yasal belgeler dışında başka destekleyici belgelere de ulaşıldıysa fakat bunlara rehberde değinilmediyse tercih edilmiştir. Bu bağlamda bu koda ilişkin rehberin "Yönetim Faaliyetleri" bölümünün "Denetim, İzleme ve Değerlendirme" alt başlığında yer alan "Elektronik ortamda yürütülmesi gereken iş ve işlemlerle ilgili gerekli takip ve denetimin yapılması durumu (MEB Ortaöğretim Kurumları Yönetmeliği Md. 78/4/u; 221)" ifadesi örnek gösterilebilir. Görüldüğü üzere, denetim rehberinde MEB Ortaöğretim Kurumları Yönetmeliği'nden iki maddeye gönderme yapılmıştır. Bu maddelerin içeriğinde; "okul müdürünün elektronik ortamda yürütülmesi gereken iş ve işlemlerle ilgili gerekli takip ve denetimden sorumlu olmasından (Madde $78 / 4 / u$ ), bu yönetmelik kapsamındaki iş ve işlemlerden elektronik ortamda yapılabilir olanların elektronik ortamda yapılmasından, elektronik ortamda arşivlenmesi mümkün olmayan evrakların çıktılarının alınmasının, onaylanmasının ve usulüne uygun olarak saklanmasının gerekliliğinden (Madde 221/1)" bahsetmektedir. Buna karşın aynı yönetmelikte yer alan "okul müdürünün; mezunların elektronik ortamda izlenmesinden, gerektiğinde mezunlar ve işyeri yetkililerine anket uygulanmasını sağlanmasından, okulun yıllara göre mesleki ve akademik başarısını tespit ederek sonuçlarından yararlanmasından sorumlu olduğuna yönelik maddeye (78/5/c) ve okul müdür yardımcılarının elektronik ortamda veri tabanı üzerinden bilgi alış verişiyle ilgili işlemleri yürütmesine yönelik maddeye (80/2/d)" gönderme yapılmamıştır. Bunun dışında elektronik ortamda yürütülmesi gereken iş ve işlemlere yönelik aynı yönetmelikte daha birçok yasal dayanak bulunmaktadır fakat bunlara değinilmediği için rehberdeki bu ifade "ilgili yasal dayanağa eksik gönderme" kodu kapsamına alınmıştır. Bunlardan bazıları şöyledir: Ders seçimi (Madde 11), Kayıt (Madde 21-22-27), Alan ve dala geçiş (Madde 31), Devam-devamsızlık ve ilişik kesme (Madde 36), Kontenjan belirleme, başvuru ve değerlendirme (Madde 38), Yetenek sınavıyla öğrenci alan okullar arasında nakiller (Madde 39), Puanla değerlendirme (Madde 44), Yazılı ve uygulamalı sınavlar (Madde 45), Ölçme ve değerlendirme sonuçlarının duyurulması 
(Madde 49), Performans çalışması, proje ve diğer çalışmalar (Madde 50), Dönem puanı (Madde 51), Yılsonu başarı puanı (Madde 55), Okul birincilerinin tespiti (Madde 64), Karne düzenlenmesi (Madde 68), Diploma düzenlenmesi (Madde 69), Değerlendirme (Madde 133), Cezaların işlenmesi, silinmesi, puan iadesi ve dosyaların saklanması (Madde 171). Bu koda yönelik ifadelerin çok çıkması rehber hazırlanırken detaya dikkat edilmemesi olabilir. Diğer yandan, denetim rehberinde "Denetim rehberinde yer almayan hususlar için ilgili mevzuat hükümlerine göre rehberlik ve denetim yapılacaktır. Rehberde yer alan mevzuat atıfları bilgi amaçlıdır" diye belirtilerek intiyaç duyulan konularda maarif müfettişine ve okul yöneticilerine meşguliyet çıkarıcı bir özellikten de söz edilebilir. Ayrıca bir rehberin en önemli özelliğinin "yol göstericilik" olduğu da gözden ırak tutulmamalıdır.

"Yasal boşluk ( $n=6)$ " kodu rehberde yer alan içeriğe yönelik herhangi bir yasal belge yoksa tercih edilmiştir. Bu doğrultuda rehberin "Yönetim Faaliyetleri" bölümünün "Yazı İşleri" alt başlığında yer alan "Brifing dosyasının güncellenmesi" ifadesine yönelik hiçbir yasal belgede açık bir hükme rastlanmamıştır. Bu kodda yasal dayanağı olmayan bazı ifadelerin varlığı bu faaliyetlerin okullarda daha çok uygulama yoluyla yürütülmesinden dolayı yasal zemine gerek duyulmaması ya da MEB mevzuatı hazırlanırken göz ardı edilmiş olması olabilir.

"Yasal dayanağa internet ortamında ulaşamama $(n=6)$ " kodu rehberin içeriğinde gönderme yapılan yasal belgeye internet ortamında ulaşılamadıysa kullanılmıştır. Bu duruma ilgili belgenin çok eski olmasının ya da yürürlükten kaldıılmasının etkisinin olabileceği düşünülmektedir. Bu bağlamda söz konusu koda yine rehberin "Yönetim Faaliyetleri" bölümünün "İnsan Kaynakları İs ve İşlemleri" alt başlığında yer alan "Özlük dosyalarının 'Özlük Dosyası Devamlı Talimatına' göre düzenlenmesi (2005/41 Sayılı Genelge)" ifadesi örnek olarak gösterilebilir. Yapılan araştırmalar sonucunda böyle tarihli ve sayılı bir genelgeye ne güncel olan genelgelerde ne de mülga olanlarda ulaşılamamışır. Bu bulguya ulaşılmasının nedeni söz konusu yasal belgelerin eski olması ya da internet ortamına yüklenmemiş olması şeklinde açıklanabilir.

Kodlardan biri de "Yasal dayanağa göre eksik ifade edilmedir $(n=5)$." Bu kod kapsamında rehberin amaç, kapsam, dayanak ve tanımlar bölümündeki; "Denetim, Rehberlik, Rehberlik ve Denetim Bilgi İşlem Sistemi, Denetim Emri, Grup Sorumlusu, Rehberlik ve Denetim Öncesi Hazırlık Toplantısı, Çalışma Planı, Bilgi Notu (Föy), Değerlendirme Toplantısı, Rapor, Raportör, Gelişim Planı" gibi kavram tanımlamalarına dönük ifadeler örnek olarak verilebilir. Bu tanımlarda eksik olan rehberde "Yabancı okullar", "Azınlık okullar" ve "Milletlerarası okullar" ile ilgili tanımların verilmemiş olmasıdır. Bu okullara yönelik tanımlar yasal dayanağı olan Özel Öğretim Kurumları Kanunu'nun 2. Maddesinin d, e ve I bendinde yer almaktadır: "d) Yabancı okullar: Yabancılar tarafından açılmış özel okulları, e) Azınlık okulları: Rum, Ermeni ve Musevî azınlıklar tarafından kurulmuş, Lozan Antlaşması ile güvence altına alınmış ve kendi azınlığına mensup Türkiye Cumhuriyeti uyruklu öğrencilerin devam ettiği okul öncesi eğitim, ilköğretim ve ortaöğretim özel okullarını, l) Milletlerarası özel öğretim kurumları: Yalnı yabancı uyruklu öğrencilerin devam edebilecekleri özel öğretim kurumlarını ifade eder." Bu eksikliğin bir nedeni rehberin hazırlanışında mevzuattan derinlemesine yararlanılmaması olabilir.

En az ifadeye rastlanan kodlardan biri "Yasal dayanağın hatalı ifade edilmesi $(n=3)$ " olmuştur. Bu kod; gönderme yapılan yasal belgede madde numarası doğru değilse ya da gönderme yapılan yasal belgenin kendisi doğru ifade edilmemişse tercih edilmiştir. Bu doğrultuda, rehberin "Eğitim-Öğretim Faaliyetleri" bölümünün "Eğitim-Öğretim Ortamları" alt başlı̆̆ında yer alan "Sivil savunma önlemleri yanı sıra okulun iç-dış güvenliği ile sabotajlara karşı gerekli önlemlerin alınması (Binaların Yangından Korunması Hakkında Yönetmelik, 28/12/1988 tarih ve 20033 Sayılı Resmi Gazete- Sabotajlara Karşı Koruma Yönetmeliği; MEB Koruyucu Güvenlik Özel Talimatı-1423-2491 Sayılı Tebliğler Dergisi- Savunma Sekreterliği çıkışlı 2005/62 Sayılı Genelge)" ifadesi bu kodla ilişkilendirilebilir. Burada atıf yapılan 2491 Sayılı Tebliğler Dergisi'nde sivil savunmaya yönelik bir içerik bulunmamakta aksine eğitim-öğretim sürecinde 
okutulacak ders kitaplarına yönelik içeriğe rastlanmaktadır. Ayrıca Savunma Sekreterliği çıkışlı genelgenin sayısının da 62 şeklinde yanlış ifade edilmiştir. 52 sayılı genelge olması gerekmektedir. Rehberin hazırlanması esnasında ilgili yasal belgeye ulaşarak içeriğinin teyit edilmemesi ya da rehberin hazırlanmasından sonra gerekli kontrollerin yapılmaması bu durumun ortaya çıkmasına yol açmış olabilir.

"Yasal dayanağa göre fazla ifade edilme $(n=1)$ " en az ifadesi olan kodlardan bir diğeridir. $\mathrm{Bu}$ kod rehberde fazla veya detaylı ifade edilmiş maddeler varsa kullanılmıştır. Örneğin, 20.08.2017 tarihli ve 30160 sayılı Teftiş Kurulu Yönetmeliği'nin 47. maddesinde ve rehberde denetimin ilkelerinin çoğu aynı şekilde verilmiştir fakat birkaç ilke rehberde daha fazladır. Aşağıda sadece rehberde göze çarpan fazla ifadeler bu koda alıntı olarak verilmiştir:

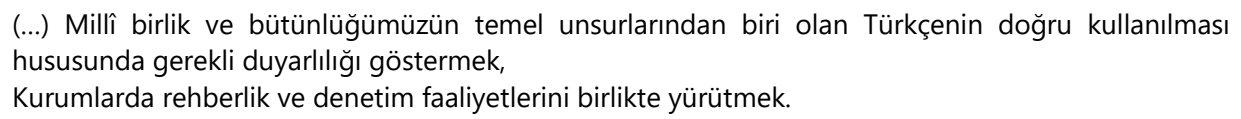

Rehberdeki ve ilgili yönetmelikteki ilkeler incelendiğinde çoğunun aynı ya da uyumlu olduğu fakat rehberde ilkelerin dayandıkları yasal belgeye göre daha fazla ilke içerdiği veya daha kapsamlı şekilde ifade edildiği görülmektedir. Rehberdeki Türkçe'nin doğru kullanımıyla ilişkili ilke buna bir örnektir. Böyle bir ifadeyi ilke olarak yazmanın gereğini anlamak da oldukça zordur. Zira hem Türkiye'de resmi işlerin tümünde hem de eğitim dili olarak tek dil Türkçe'dir. Ancak gerek okul yöneticilerinin gerekse maarif müfettişlerinin niteliğinden şüphe duyulursa onları buna özellikle zorlamak adına anlaşılabilir gibi de durmaktadır.

Son olarak, "Karşılıksız" kodu en az ifadeye rastlanan bir diğer koddur. Bu kod rehberde gönderme yapılan yasal belge yürürlükten kaldırılmışsa ve yerine güncel olanı hazırlanmadığı için ilgili ifadeye karşılık gelen bir yasal dayanak yoksa tercih edilmiştir. "Eğitim-Öğretim Faaliyetleri" başlığının "Öğretim Etkinlikleri" alt başlığında yer alan "Öğrenci velileri ve kamuoyunun, okulun amaçları ile eğitim-öğretim etkinlikleri konusunda bilgilendirilmesi (MEB Özel Eğitim ve Rehberlik Hizmetleri Genel Müdürlügü̈ çıkışlı 2002/27 Sayılı Genelge; Ortaöğretim Genel Müdürlüğü çıkışlı 2006/22 Sayll Genelge)." ifadesi "Karşılıksız" kodu ile ilişkilendirilebilir çünkü 2002/27 sayılı "Okul-Veli İşbirliği Genelgesi" güncelliğini yitirdiğinden dolayı yürürlükten kaldırılmıştır ve yerine yeni bir genelge hazırlanmadığı tespit edilmiştir. Bu durumun bir nedeni, eskiden var olan ve kullanılan bir yasal belgeye zemin hazırlayan hususların değişmesi, ortadan kalkması ve bunlara binaen de mevzuatına ihtiyaç kalmaması olabilir.

\section{2- Denetim Rehberinin Alanyazınla iliş̧kisi}

Aşağıda yer alan Tablo 3'te "Denetim rehberinin alanyazınla ilişkisi teması" altında "Denetim rehberinin alanyazınla tutarlılı̆ı" ve "Denetim rehberinin alanyazınla tutarsızlığı" kategorileri ile kodları verilmiştir. Bu kısımda denetim rehberi ya da okullar ile ilgili doğrudan bir alanyazın çalışmasının yokluğuna binaen dolaylı çalışmalar temelinde hareket edildiğinden sayısallaştırmaya gidilmemiştir.

\subsection{Denetim Rehberinin Alanyazınla Tutarlılığı}

Yapılan analiz sonucu rehberin alanyazınla genel olarak tutarlı olduğu görülmüştür. Bu bağlamda, rehberin "Yönetim Faaliyetleri" bölümünün "Araştırma ve Planlama" alt başlığında yer alan "Öğretmen ders dağlımlarının ve ders programlarının pedagojik esaslar göz önünde bulundurularak hazırlanması (MEB Ortaöğretim Kurumları Yönetmeliği Md. 11, 12)" ifadesi "Denetim rehberinin alanyazınla tutarlılı̆ı" temasının "Uygunluk" koduna bir örnek olarak verilebilir çünkü pedagojik esasların dikkate alınması bilimin temel alınması demektir. Rehberin genel olarak alanyazınla tutarlı çıkmasının nedeni denetim alanyazınının mevzuat ve kurumlardaki uygulamalarla birbirini besleyen nitelikte olması olabilir. Eğitim denetimi biliminin ürettiği bilgiden istifade eden bir denetim anlayışı temelinde bu durumun sevindirici olduğu da söylenebilir. 


\subsection{Denetim Rehberinin Alanyazınla Tutarsızlığı}

Denetim rehberinin incelenmesi sonucu alanyazınla tutarsız olan noktalar tespit edilmiştir. Buna göre Tablo 3'te analiz sonucu ortaya çıkan tema, kategori ve kodlar verilmiştir.

Tablo 3 "Denetim rehberinin alanyazınla ilişkisi" teması altında ortaya çıkan kategori ve kodların dağılımı

\begin{tabular}{|c|c|c|}
\hline Tema & Kategoriler & Kodlar \\
\hline \multirow{5}{*}{ 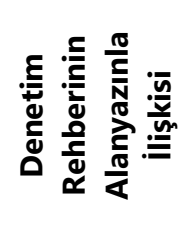 } & 1. Denetim Rehberinin Alanyazınla Tutarlılığı & Uygunluk \\
\hline & \multirow{4}{*}{ 2. Denetim Rehberinin Alanyazınla Tutarsızlığı } & İçerik eksikliği \\
\hline & & Atıfsızlık \\
\hline & & Kavram tutarsızlığı \\
\hline & & Aykırılık \\
\hline
\end{tabular}

Tablo 3'te görüldüğü gibi, "Denetim rehberinin alanyazınla ilişkisi" temasının "Denetim rehberinin alanyazınla tutarsızlığı" kategorisi kapsamında "içerik eksikliği", "Atıfsızlık", "Kavram tutarsızlığı" ve "Aykırılık" olmak üzere dört kod tespit edilmiştir.

"Denetim rehberinin alanyazınla tutarsızlı̆ı" kategorisinin "içerik eksikliği" kodu alanyazında olan fakat rehberde olmayan durumlar tespit edildiğinde tercih edilmiştir. Bu bağlamda, rehberin tanımlar bölümü örnek gösterilebilir. Bu bölümde; "Denetim, Rehberlik, Rehberlik ve Denetim Bilgi Işlem Sistemi, Denetim Emri, Grup Sorumlusu, Rehberlik ve Denetim Öncesi Hazırlık Toplantısı, Çalışma Planı, Bilgi Notu (Föy), Değerlendirme Toplantısı, Rapor, Raportör, Gelişim Planı" kavramlarının tanımları verilmiştir. Eğitim denetimi alanyazını temel alınarak "Denetim türleri (ders denetimi, kurum denetimi)", "Denetim kuramları (bilimsel, sanatsal, kliniksel, farklılaştırılmış, gelişimsel, öğretimsel)", "Denetimin boyutları (yönetim, program, yönetim)" gibi kavramların olmadığı tespit edilmiştir. Bunun dışında, eğitim politikalarına ilişkin uygulamalarda taahhüt sistemi olarak düşünülen hesap verebilirlik ilkesi yine rehberde eksikliği tespit edilen konulardan bir diğeridir. Bunun bir nedeni denetim rehberini hazırlayan kişilerin bilimsel yöntemle hareket etmemesi olabileceği gibi yoğun şekilde mevzuata yönelik eğitime tabi tutulmalarıla biçimlenen personel ya da denetim yöneticileri olabilir. Türkiye'de müfettiş yetiştirme kısa süreli kurslar yoluyla yapıldığı için müfettişler, mesleğe yönelik gerekli bilgi, beceri ve tutumlarla donatılamamakta ve bu durum bir müfettiş yetiştirme sorunu olarak görülmektedir (Gündüz ve Balyer, 2012).

"Atıfsızlık" kodu, alanyazınla ister tutarlı olsun ister tutarsız olsun rehberin konusu ile ilgili yapılmış bilimsel çalışmalara gönderme yapmama durumunu ifade etmektedir. Örneğin rehberde geçen "Sorunlar tespit edilirken; mevzuat, üst politika belgeleri (Kalkınma Planı, Hükümet Programı, Millî Eğitim Bakanlığı Stratejik Planı) ile okul/kurumun stratejik planında eğitim ile ilgili ortaya konulmuş amaç ve hedefler göz önünde bulundurulur." ve "Herhangi bir süreç ile ilgili tespit edilen sorunlar ilgili başlıklar açılarak yazılır. Bakanlığa, il / ilçe milli eğitim müdürlügüne, okula yönelik olarak; kurumun gelişimine katkı sağlayacak, değer katacak, geleceğe ilişkin bir vizyon oluşturacak, aynı zamanda gerçekçi ve uygulanabilir önerilere yer verilmelidir." ifadeleri bu kodla ilişkilendirilebilir. Sorunlar ve çözümler bölümünde alanyazına atıf yapılarak araştırmacıların tespit ettiği sorunlara ulaşılabilir ve ne gibi önerilere yer verildiğine atıflar yapılabilir. Bu bulgunun elde edilmesinin sebebi olarak rehberin sadece mevzuat odaklı hazırlanarak bilimsel bilginin göz ardı edilmesi şeklinde açıklanabilir. Diğer yandan rehberin var olan haliyle alanyazınla tutarlı çıkan yanları itibariyle o kısımların gönderme yaptığı mevzuatın şekillenişi ya da oluşturulması esnasında bilimsel bilgiden hareket edilmiş olabileceğine ilişkin bir ipucu da verebilir. Eğitbilimciler tarafından hazırlanan eğitim pratiğinin teorileri üretildiği toplumun ve belki de uluslararası toplumun gerçekten yasal belgelerine yansıdığında ancak eğitimin bilimliliğinden söz edilebilir (Toprakçı, 2008; Toprakçı, Dağdeviren, Oflaz ve Türe 2010). 
"Kavram tutarsızlığı" kodu, alanyazın ve rehberdeki kavramların kullanımının tutarsız olduğu ya da birbirini kapsayan kavramlar tespit edildiğinde tercih edilmiştir. Bu bağlamda rehberde çok sık şekilde denetim ve rehberlik kavramlarının birlikte kullanıldığı belirlenmiştir. Oysa denetim, rehberliği de içine alan bir kavramdır. Rehberin tanımlar bölümündeki denetimin tanımında da rehberlik kavramı geçmektedir. Bunun dışında açıklık ve şeffaflık gibi kavramların yine rehberlik ve denetim ilkelerinde birlikte kullanıldığı görülmüştür. Bu bulguya ulaşılması rehberi hazırlayan kişilerin denetim alanyazınını gerekli yerlerde temel almamalarından kaynaklanmış olabilir.

"Aykırllk" kodu, denetim rehberinde alanyazınla çelişen ve düzeltilmesi gereken bir durum varsa tercih edilmiştir. Bu bağlamda "Rehberlik ve Denetim Esasları" bölümünün "Rehberlik ve Denetim Sürecinin Planlanması ve Yürütülmesi" alt başlığında yer alan "Ön Çalışma; Bilgi Toplama/Ön Araştırma, Potansiyel Sorunlu Alanlar, Rehberlik ve Denetim Araçlarının Belirlenmesi ile Rehberlik ve Denetim Öncesi Hazırlık Toplantısı safhalarından oluşur." ifadesi bu kod kapsamında incelenebilir. Buna ek olarak, ön çalışmanın devamındaki "Alanda Rehberlik ve Denetim Uygulaması" bölümünde yer alan "Rehberlik ve Denetim Uygulama Süresi, Bulguların Elde Edilmesi ve Önerilerin Geliştirilmesi, Bulguların Denetlenen Kurumla Paylaşılması, Değerlendirme Toplantısı" ifadeleri de bu kodla ilişkilendirilebilecek diğer ifadedir. Görüldüğü üzere, burada denetimin aşamaları anlatılmaktadır. Fakat alanyazına göre her denetim modelinin kendine özgü aşamaları bulunmaktadır. Örneğin, gelişimsel denetim sürecinin uygulanmasında, en uygun davranışın seçilmesi, seçilen davranışın uygulanması ve öğretmen gelişiminin sağlanması şeklinde üç aşama yer almaktadır (Aydın, 2005). Buna ek olarak, alanyazında kliniksel denetim; gözlem öncesi görüşme, gözlem yapma, analiz yapma, gözlem sonrası görüşme, değerlendirme olmak üzere beş aşamadan oluşmaktadır (Taymaz, 2013). Böyle bir bulgunun bir nedeni, rehberin sadece yasal mevzuat temelinde hazırlanması, rehberi hazırlayan görevlilerin daha çok mevzuata ilişkin sınavlara tabi tutulmaları ve eğitim almaları olarak gösterilebilir.

\section{SONUÇ VE ÖNERILER}

Araştırmanın bu bölümünde elde edilen sonuçlara her bir tema, kategorileri ve kodları bazında yer verilmiştir. Sonra da eğer yapılabiliyorsa bunların her birinin altına araştırmacı ve uygulamacılar için önerilere yer verilmiştir.

1. Illk sonuç olarak belirtmek gerekir ki rehber alanyazın ve yasalarla ilişkilidir. Bu ilişkinin her iki kategori (alanyazın ve yasalar) temelinde yarı yarıya tutarlı ve tutarsız olduğu söylenebilir.

- Tutarlı kısımların tutarlıı̆ııın devamlıı̆̆ını sağlamak gerektiği uygulamacılara önerilebilir. Zira biraz da söz edilecek olan ve tutarsızlığı ortaya koyan sonuçlara bakılarak eğer inmaller söz konusu olursa bu kısımların da zamanla tutarsızlaşabileceği söylenebilir. Diğer yandan araştırmacılar bu tutarlığı nicel olarak da ortaya koyan araştırmalar yapabilirler.

Rehberin tutarsız olan kısımlarına dair sonuçlar ve öneriler, rehberin yasal belgeler ile tutarsızlığını biçimleyen kodlar temelinde, şöyledir:

1. Rehberde gönderme yapılan yasal belgelerin bir kısmının güncel olmadığı ya da yürürlükten kaldırıldığı belirlenmiştir.

- Bu bağlamda, uygulayıcılara rehberlerin hazırlanması ve güncellenmesi için bir birim kurulması önerilebilir.

- Rehberlerin temel alınıp alınmadığını, denetim esnasında müfettişler tarafından kullanılıp kullanıımadığını, söz konusu rehberlerin güçlü ve zayıf yönlerinin neler olduğunu tespit 
etmek için maarif müfettişlerinden oluşan çalışma grubuyla görüşme yapılarak bir çalışma yürütülmesi araştırmacılara tavsiye edilebilir.

2. Rehberdeki bazı ifadelerde ilgili yasal belgeye gönderme yapılmadığı görülmüştür.

- Bu doğrultuda uygulayııılara eğitim-öğretim ve denetimle ilişkili olabilecek tüm yasal belgelerin güncel ve mülga versiyonlarının bir havuzda toplanarak Teftiş Kurulu Başkanlığı'nın resmi internet sitesine koyulması önerilebilir. Böylece rehberleri hazırlayan görevliler için yasal belgelere ulaşmak daha kolay olacaktır.

- Araştırmacılara ise maarif müfettişlerinin denetim rehberlerini kullanarak denetimi gerçekleştirme düzeylerini tespit etmek için ölçek geliştirmeleri tavsiye edilebilir.

3. Rehberdeki bazı ifadelerde yasal dayanaklara eksik gönderme yapıldığı belirlenmiştir.

- Bu bağlamda, maarif müfettişlerinin güncel mevzuattan haberdar olması için uygulayıcılar tarafından hizmet içi eğitimlerin düzenlenmesi sağlanmalıdır.

- Araştırmacılara ise, denetimle ilgili mevzuatın incelenmesine yönelik çalışmalar yapmaları önerilebilir.

4. Rehberde yer alan bazı ifadelerin yasal dayanağının olmadığı tespit edilmiştir.

- Rehberlerin içinde yer alan ifadelerin gözden geçirilerek yasal zeminin oluşturulması uygulama birliğinin sağlanması açısından önem arz etmektedir. Bunun için uygulayıcılara yasal temeli olmayan hususların tespit edilip yasal zemine oturtulması tavsiye edilebilir.

5. Rehberde gönderme yapılan yasal belgelerin bir kısmına internet ortamında ulaşılamamışır.

- Bu bağlamda uygulayııların denetim rehberini hazırlarken yasal belgelerin güncelliğini ve yürürlükten kaldırılıp kaldırılmadığını kontrol etmesi gerekir. Bunun için internet ortamında yer almayan yasal belgelerin ya da eklerin Teftiş Kurulu Başkanlığı'nın resmi sitesine yüklenmesi sağlanabilir.

- Araştırmacılara ise, çeşitli ülkelerde eğitim denetimini ilgilendiren yasal düzenlemelerin neler olduğu ve bunlara ne şekilde ulaşıldığını içeren karşılaştırmalı çalışmalar yapması önerilebilir.

6. Rehberde yer alan bazı ifadelerin yasal belgedeki haline göre eksik, fazla ya da hatalı ifade edildiği görülmüştür.

- Bu doğrultuda, maarif müfettişlerinin rehberlerin ve ilgili mevzuatın içeriği hakkında tartışmalar yaparak uygulayıcılara tavsiyede bulunabilecekleri konferans ya da paneller düzenlenmelidir.

- Rehberlerin hazırlanmasından önce, hazırlanma esnasında ve hazırlanmasından sonra olmak üzere üç aşamalı bir izleme-değerlendirme süreci yürütülmelidir.

- Araştırmacılara ise rehberlerin hazırlanma sürecinde yaşanan aksaklıklara yönelik maarif müfettişlerinden oluşan bir çalışma grubuyla nitel bir araştırma yapmaları önerilebilir.

7. Yasal belgenin yürürlükten kaldırılmasından ve yerine yenisinin hazırlanmamasından dolayı rehberdeki bazı ifadelerin yasal dayanak açısından karşılığının olmadığı sonucuna ulaşılmıştır.

- Bu bağlamda, rehberlerin nitelikli hazırlanıp hazırlanmadığını, rehberlerin içinde yer alan mevzuatın güncel olup olmadığını tespit etmek için rehberlerin hazırlanmasında görevli olan kişilerin yürüttüğü süreçte denetlenmelidir.

- Yine bu sonuç bağlamında araştırmacılara denetim rehberlerinin içerik ve biçimsel açıdan nasıl olması gerektiği konusunda bir model oluşturmaları tavsiye edilebilir. 
Rehberin tutarsız olan kısımlarına dair sonuçlar ve öneriler, rehberin alanyazın ile tutarsızlığını biçimleyen kodlar temelinde, şöyledir:

1. Rehberdeki bazı ifadelerin içeriğinde alanyazına göre eksiklikler olduğu görülmüştür.

- Bu bağlamda, uygulayıcılara denetim rehberlerinin hazırlanmadan önce bilimsel çalışmaların sonuç ve önerilerinin incelenmesi önerilebilir çünkü bilimin temel alındığı bir kılavuz oluşturulması rehberi daha nitelikli hale getirecektir.

- Araştırmacılara ise, rehberlerin yabancı ülkelerde hazırlanan rehberlerle karşılaştırılması ve bu bağlamda olumlu ve olumsuz yönlerinin belirlenmesi önerilebilir.

2. Rehberindeki ifadelerin hiçbirinde bilimsel çalışmalara gönderme yapılmadığı belirlenmiştir.

- Bu doğrultuda, maarif müfettişlerinin bilimsel çalışmaları temel alan hizmet içi eğitimlere tabi tutulmasının sağlanması uygulayıcılara tavsiye edilebilir.

- Araştırmacılara ise, denetim rehberlerinin bilimsel alt yapısına hizmet edecek denetim kuramlarının geliştirilmesi yönünde alanyazına katkı sağlamaları önerilebilir.

3. Rehberdeki kavramların bir kısmının kullanımının alanyazınla tutarsız olduğu ya da birbirini kapsayan kavramlar kullanıldığı tespit edilmiştir.

- Bu sonuç bağlamında, alanyazın temelinde denetim rehberinin hazırlanması ve kontrolünün yapılması için bilim uzmanlarından oluşan bir ekip oluşturmaları uygulayıcılara tavsiye edilebilir.

- Ayrıca, denetim türlerini, denetim kuramlarını ve bu kuramlara göre aşamaları temel alan, kurumların değişen özellikleri ve ihtiyaçlarına göre rehberler hazırlanmalıdır.

4. Rehberde alanyazınla çelişen ve düzeltilmesi gereken ifadeler olduğu görülmüştür.

- Bu sonuca göre, alanyazına hakim olmaları için maarif müfettişlerinin lisansüstü eğitim almalarına yönelik teşvik edilmeleri gerekir. Bu bağlamda maarif müfettişi olma kriterlerinin düzenlenmesi ve mevcut maarif müfettişlerinin kişisel gelişimlerine yaptıkları katkıların karşıı̆ını almaları için gerekli yasal düzenlemelerin yapılması uygulayıcılara önerilebilir.

- Son olarak yabancı okullardan, azınlık okullarından ya da milletlerarası okullardan kurumlar seçilerek ve bu kurumların denetimleri sonucu hazırlanan denetim raporlarına ulaşarak incelenmesi de araştırmacılara tavsiye edilebilir.

\section{KAYNAKLAR}

Aydın, I. (2005). Ögretimde denetim. Ankara: Pegem A Yayıncılık.

Aydın, M. (2014). Çağdaş eğitim denetimi (6. baskı). Ankara: Gazi Kitabevi.

Creswell, J. W. (2002). Educational research: Planning, conducting, and evaluating quantitative. Prentice-Hall Upper Saddle River, NJ.

Creswell, W. J. (2003). Research design: Qualitative, quantitative, and mixed methods approaches. London: SAGE Publications.

Demirtaş, H. ve Güneş, H. (2002). Eğitim yönetimi ve denetimi sözlüğü. Ankara: Anı Yayıncılık.

Ertuğrul, H. (1997). Kuruluşundan günümüze azınlık ve yabancı okulları ve bu okullardan mezun olan ögrrencilerin Türk toplumunda üstlendiği roller. Doktora Tezi. Sakarya Üniversitesi Sosyal Bilimler Enstitüsü, Sakarya.

Gündüz, Y. ve Balyer, A. (2012). Türkiye'de ve bazı Avrupa ülkelerinde müfettişlerin yetiştirilme süreci ve karşılaşılan sorunlar. Mersin Üniversitesi Eğitim Fakültesi Dergisi, 8(1), 84-95.

Haydaroğlu, ì. (2008). Osmanlı Devleti'nde yabancı okullarda denetim ve Cumhuriyet dönemine yansımaları. Tarih Araştırmaları Dergisi, 25(39), 149-160. 
Kayıkçı, K. ve Şarlak, Ş. (2013). İlköğretim okullarında performans değerlendirme: Öğretmenlerin sicil uygulamasına ilişkin görüşleri. Electronic Journal of Social Sciences, 12(43).

Kayıkçı, K. (2016). Türkiye'de eğitim denetim sorunları ve çözüm önerileri. Eğitimde denetim ve değerlendirme (1. Baskı, ss. 383-407). Ankara: Pegem Akademi.

Kayıkçı, K., Özyıldırım, R. A. G. ve Özdemir, İ. (2016). The assessment of school administrators' selection policy in regards to equality and assurance principles and its effect on their loyalty/Okul yöneticilerinin seçiminin eşitlik ve güvence ilkelerine göre değerlendirilmesi ve bu uygulamanın yöneticilerin sadakatlerine etkisi. e-Uluslararası Eğitim Araştırmaları Dergisi, 7(1).

Kış, A., Konan, N. ve Sönmez, H. (2011). Öğretmen teftiş formlarının değerlendirilmesi. III. Uluslararası Katılımlı Eğitim Denetimi Kongresi, 22-24 Haziran 2011, Mersin Üniversitesi, Çiftlikköy Kampüsü, Mersin, ss. 558-570.

Konan, N., Kış, A. ve Demir, A. (2011). Yönetici teftiş formlarının değerlendirilmesi. III. Uluslararası Katılımlı Eğitim Denetimi Kongresi, 22-24 Haziran 2011, Mersin Üniversitesi, Çiftlikköy Kampüsü, Mersin, ss. 571-582.

Konan, N., Kış, A. ve Kırbaç, M. (2011). Eğitim müfettiş yardımcıları eğitimi kursuna ilişkin eğitim müfettiş yardımcılarının görüşleri. III. Uluslararası Katılımlı Eğitim Denetimi Kongresi, 22-24 Haziran 2011, Mersin Üniversitesi, Çiftlikköy Kampüsü, Mersin, ss. 132-146.

Konan, N. ve Çoban, D. (2013). il eğitim denetmenlerinin "yönetici teftiş formu"nda yer alan değerlendirme ölçütlerine ilişkin görüşleri. 8. Ulusal Eğitim Yönetimi Kongresi, 07-09 Kasım 2013, Marmara Üniversitesi, İstanbul, ss: 115-116.

Konan, N. ve Çoban, D. (2013). ilkokul ve ortaokul yöneticilerinin "yönetici teftiş formu"na ilişkin görüşleri. Eğitim Yönetimi Forumu (EYFOR) - IV, 3-5 Ekim 2013, Balıkesir Üniversitesi, Balıkesir, ss: 45-48.

Konan, N. ve Oğuz, V. (2014). Okul öncesi öğretmenlerinin öğretmen teftiş formundan aldıkları puanların analizi. Mersin Üniversitesi Eğitim Fakültesi Dergisi, 10(3), 123-136.

Konan, N. ve Oğuz, V. (2015). Okul öncesi öğretmenlerinin öğretmen teftiş formunda yer alan değerlendirme ölçütlerine ilişkin görüşleri. Electronic International Journal of Education, Arts, and Science, $1(1), 62-76$.

MacGilchrist, B. ve Mortimore, P. (1997). The impact of school development plans in primary schools. School Effectiveness and School Improvement, 8(2), 198-218.

Milli Eğitim Bakanlığı [MEB] (1966). 1423 Sayılı Tebliğler Dergisi, http://tebligler.meb.gov.tr/index.php/tuem-sayilar/viewcategory/30-1966?start=24, Erişim tarihi 10.05 .2020

Milli Eğitim Bakanlığı [MEB] (1967). 1442 sayılı Tebliğler Dergisi, http://tebligler.meb.gov.tr/index.php/tuemsayilar/viewcategory/31-1967?start=24, Erişim tarihi 10.05.2020

Milli Eğitim Bakanlığı [MEB] (1983). Millî Eğitim Bakanlığı'na Bağlı Okul Pansiyonları Yönetmeliği, http://mevzuat.meb.gov.tr/dosyalar/91.pdf, Erişim tarihi 12.05 .2020

Milli Eğitim Bakanlığı [MEB] (1998). 2491 Sayllı Tebliğler Dergisi, http://tebligler.meb.gov.tr/index.php/tuem-sayilar/viewcategory/62-1998, Erişim tarihi 10.05.2020

Milli Eğitim Bakanlığı [MEB] (2001). Rehberlik ve Psikolojik Danışma Hizmetleri Yönetmeliği (mülga), http://mevzuat.meb.gov.tr/dosyalar/55.pdf, Erişim tarihi 11.05.2020

Milli Eğitim Bakanlığı [MEB] (2002). Okul-Veli İşbirliği konulu Genelge (2002/27 sayıll, mülga), http://mevzuat.meb.gov.tr/dosyalar/1381.pdf, Erişim tarihi 12.05.2020

Milli Eğitim Bakanlığı [MEB] (2005). Okul ve Kurumlarda Oluşturulan Yangın Köşesi konulu Genelge (2005/52 saylli), http://mevzuat.meb.gov.tr/dosyalar/1403.pdf, Erişim tarihi 10.05.2020

Milli Eğitim Bakanlığı [MEB] (2006). Özel Eğitim Hizmetleri Yönetmeliği (mülga), http://mevzuat.meb.gov.tr/dosyalar/393.pdf, Erişim tarihi 11.05.2020

Milli Eğitim Bakanlığı [MEB] (2006). Millî Eğitim Bakanlığı Kurum Tanıtım Yönetmeliği, https://www.mevzuat.gov.tr/mevzuat?MevzuatNo=10567\&MevzuatTur=7\&MevzuatTertip=5, Erişim tarihi 11.05 .2020

Milli Eğitim Bakanlığı [MEB] (2006). Öğrencilerimizin Zararı Madde Kullanımı ve Şiddet Gibi Risklerden Korunması konulu Genelge (2006/22 sayll), http://mevzuat.meb.gov.tr/dosyalar/1333.pdf, Erişim tarihi 12.05.2020

Milli Eğitim Bakanlığı [MEB] (2008). Kaynaştırma Yoluyla Eğitim Uygulamaları konulu Genelge (2008/60 sayll), http://mevzuat.meb.gov.tr/dosyalar/1425.pdf, Erişim tarihi 12.05.2020

Milli Eğitim Bakanlığı [MEB] (2012). Özel Öğretim Kurumları Yönetmeliği, https://www.mevzuat.gov.tr/mevzuat?MevzuatNo=15970\&MevzuatTur=7\&MevzuatTertip=5, Erişim tarihi 11.05.2020 
Milli Eğitim Bakanlığı [MEB] (2013). Ortaöğretim Kurumları Yönetmeliği,

https://www.mevzuat.gov.tr/mevzuat?MevzuatNo=18812\&MevzuatTur=7\&MevzuatTertip=5, Erişim tarihi 04.05.2020

Milli Eğitim Bakanlığı [MEB] (2016). Yabancı, azınlık ve milletlerarası okullar denetim rehberi, https://www.mevzuat.gov.tr/mevzuat?MevzuatNo=23861\&MevzuatTur=7\&MevzuatTertip=5, Erişim tarihi 08.05.2020

Milli Eğitim Bakanlığı [MEB] (2016). Millî Eğitim Bakanlığına Bağlı Resmî Okullarda Yatılıık, Bursluluk, Sosyal Yardımlar ve Okul Pansiyonları Yönetmeliği, http://mevzuat.meb.gov.tr/dosyalar/1812.pdf, Erişim tarihi 12.05.2020

Milli Eğitim Bakanlığı [MEB] (2017). MEB Eğitim Kurumları Sosyal Etkinlikler Yönetmeliği, https://www.mevzuat.gov.tr/mevzuat?MevzuatNo=23639\&MevzuatTur=7\&MevzuatTertip=5, Erişim tarihi 11.05.2020

Milli Eğitim Bakanlığı [MEB] (2017). Kaynaştırma/Bütünleştirme Yoluyla Eğitim Uygulamaları konulu Genelge (2017/22 sayll), http://mevzuat.meb.gov.tr/dosyalar/1870.pdf, Erişim tarihi 12.05.2020

Milli Eğitim Bakanlığı [MEB] (2017-a). Teftiş Kurulu Yönetmeliği,

https://www.mevzuat.gov.tr/mevzuat?MevzuatNo=23861\&MevzuatTur=7\&MevzuatTertip=5, Erişim tarihi 15.05.2020

Millî Eğitim Bakanlığı [MEB] (2017-b). Teftiş Kurulu Başkanlığı Görev, Yetki, Sorumluluk ve Çalışma Esaslarına Dair Yönerge, https://tkb.meb.gov.tr/meb_iys_dosyalar/2018_07/04160747_yonerge.pdf, Erişim tarihi 04.05.2020

Milli Eğitim Bakanlığı [MEB] (2018). Özel Eğitim Hizmetleri Yönetmeliği,

https://www.mevzuat.gov.tr/mevzuat?MevzuatNo=24736\&MevzuatTur=7\&MevzuatTertip=5, Erişim tarihi 11.05.2020

Milli Eğitim Bakanlığı [MEB] (2019-a). Bakanlık Maarif Müfettişleri Görev Standartları, https://tkb.meb.gov.tr/meb_iys_dosyalar/2019_06/19145017_BakanlYk_Maarif_MuYfettisYleri_GoYre v_StandartlarY.pdf, Erişim tarihi 04.06.2020

Milli Eğitim Bakanlığı [MEB]. (2020). Milli Eğitim İstatistikleri Örgün Eğitim (2019-2020). http://sgb.meb.gov.tr/www/icerik_goruntule.php?KNO=396, Erişim tarihi: 25.10.2020

Resmi Gazete (1988). Sabotajlara Karşı Koruma Yönetmeliği, https://www.mevzuat.gov.tr/MevzuatMetin/3.5.8813543.pdf, Erişim tarihi 10.05.2020

Resmi Gazete (2007). 5580 sayılı Özel Öğretim Kurumları Kanunu, https://www.mevzuat.gov.tr/MevzuatMetin/1.5.5580.pdf, Erişim tarihi 12.05.2020

Resmi Gazete (2007). Binaların Yangından Korunması Hakkında Yönetmelik, https://www.mevzuat.gov.tr/MevzuatMetin/3.5.200712937.pdf, Erişim tarihi 10.05.2020

Resmi Gazete (2018). Cumhurbaşkanlığı Teşkilatı Hakkında Cumhurbaşkanlığı Kararnamesi, https://www.resmigazete.gov.tr/eskiler/2018/07/20180710-1.pdf, Erişim Tarihi: 27.10.2020

Schein, E. H. (1978). Örgüt Psikolojisi, (M. Tosun, Çev.) Ankara: TODAiE Yayınları No:173.

Seale, C. (1999). Quality in qualitative research. Qualitative Inquiry, 5(4), 465-478.

Taymaz, H. (2013). Eğitim sisteminde teftiş: Kavramlar, ilkeler, yöntemler. Ankara: Pegem Yayıncılık.

Tilbe, H. (2016). Devlet ve azınlık okullarının yönetimsel süreçler açısından karşılaştırması. Yüksek Lisans Tezi. İstanbul Aydın Üniversitesi Sosyal Bilimler Enstitüsü, İstanbul.

Toprakçı, E. (2008). Sınıfa dayalı yönetim. Ankara: Pegem Akademi Yayıncılık.

Toprakçı, E., Çakırer, I., Bilbay, A., Bagcivan, E. ve Bayraktutan, I. (2010). Kuram ve uygulamada eğitim denetmenleri meslek etiği. Educational Policy Analysis and Strategic Research, 5(1).

Toprakçı, E., Dağdeviren, İ., Oflaz, G. ve Türe, E. (2010). Eğitim fakültesi öğretim elemanlarının bilim anlayışları temelinde eğitimin bilimliliği. Bilim ve Ütopya Dergisi, 190, 45-56.

Toprakçı, E. ve Kadı, A. (2014). Türkiye'deki bakanlıkların eğitim yönetimi ve denetimi alanındaki faaliyetlerinin yasal belgeler eşliğinde analizi. Celal Bayar Üniversitesi Sosyal Bilimler Dergisi, 12(4), 1-18.

Toprakçı, E. ve Akçay, A. (2016). Türkiye'de kamu yararına çalışan derneklerin eğitim faaliyetlerinin yönetimi ve denetimi (Yasal belgeleri temelinde nitel bir analiz). Cumhuriyet International Journal of Education-CIJE, 5(1), 29-52.

Toprakçı, E. ve Bakır, D. (2019). 2012-2017 yılları arası Milli Eğitim Bakanlığı Sayıştay denetim raporlarının incelenmesi. Y. Kondakçı, S. Emil ve K. Beycioğlu (Ed.) 14. Uluslararası Eğitim Yönetimi Kongresi içinde (s. 829-834). Ankara: Orta Doğu Teknik Üniversitesi.

Turner, U. (1970). Supervision for change and innovation. Boston: Houghton-Mifflin Company. Yıldırım, A. ve Şimşek, H. (2013). Sosyal bilimlerde nitel araştırma yöntemleri. Ankara: Seçkin Yayıncılık. 


\title{
The Examination of the Supervisory Guideline of Foreign, Minority and International Schools Based on Legal Documents and Literature
}

\author{
Prof. Dr. Erdal Toprakçı \\ Ege University-Turkey \\ erdal.toprakci@ege.edu.tr
}

\author{
Dilşad Bakır (Ph.D. Stud.) \\ Ministry of National Education-Turkey \\ dilsadbakir@hotmail.com
}

\begin{abstract}
This research examines the "the Supervisory Guideline of Foreign, Minority and International Schools" based on legal documents and literature. The document review, one of the qualitative research methods, was used in this research. The data were analyzed by content analysis. According to the results of the research, the guideline was mostly consistent with legal documents, but some of the legal documents referred to were outdated or repealed. There was no reference to the related legal document or a missing reference in some of the statements. Besides, some of the statements were incomplete according to the form in the legal document to which they were related or these statements had no legal basis. Also, some of the relevant legal documents referred to in the guideline were not available on the internet. In addition, the guideline was generally consistent with the literature, but none of the statements was referred to the literature and there were deficiencies in the content according to the literature.
\end{abstract}

Keywords: Supervisory guideline, foreign schools, minority schools, international schools

\section{Suggested Citation:}

Toprakçı, E. \&. Bakır, D. (2020). The Examination of the Supervisory Guideline of Foreign, Minority and International Schools Based on Legal Documents and Literature, E-International Journal of Educational Research, Vol: 11, No: 3, 2020, pp. 16-35, DOI: 10.19160/ijer.800326 


\section{EXTENDED ABSTRACT}

Problem: Each organization has different goals and structures designed to achieve them. Effective supervision is necessary to check the formation, continuity, strengthening and efficiency of the organizational structure. Since the supervisory system is an organizational and administrative obligation, it takes place in all organizations and every formal organization is established to achieve a specific purpose or purposes to survive (Aydın, 2014). In this context, one of the social systems that come together to serve individuals, groups or society is educational organizations. As in all organizations, supervision is necessary for educational organizations to fulfil their functions and improve themselves. The Ministry of National Education (MoNE) is responsible for educational supervision in Turkey. Institutional supervision in schools is carried out by the Ministry of National Education Inspectors according to the Inspection Board Regulation dated 20.08.2017 and numbered 30160 (MoNE, 2017). In this context, "Supervisory Guidelines" were prepared by the Inspection Board for the inspectors to use while performing their duties. One of these guidelines was for the supervision of Foreign, Minority and International schools. For this document to fulfil its duty properly, it should have as few deficiencies and errors as possible. Therefore, it may be useful to review the guideline based on the literature of educational supervision and legal documents. A supervision guideline should be based on laws. If not, problems arise. On the other hand, it should be based on scientific knowledge. Although the function of scientific knowledge to influence and determine the laws is common in societies that have transformed science into their culture, it does not seem right to say that this culture exists in our country. On this basis, this feature should be sought in the supervisory guideline of these schools. If the guidelines have this feature, a qualified supervisory activity can take place. When the literature was analyzed, very few studies were identified regarding the supervision of "Foreign and Minority schools". On the other hand, no studies regarding the supervision of "International schools" were found. Besides, there was no study related to the supervisory guideline of Foreign, Minority and International schools prepared by the Ministry of National education. With this research, "the Supervisory Guideline of Foreign, Minority and International Schools" was examined based on legal documents and literature, and suggestions were made to both practitioners and researchers.

Method: The document review, one of the qualitative research methods, was used in this research. Since the supervisory guidelines were suitable for document analysis as public documents used by the Inspection Board to ensure the unity of application in the supervision. For this reason, the stages of the document analysis were followed in this research. The Inspection Board published 16 supervisory guidelines prepared for various institutions in 2016. The document of this study was one of the published ones, "The Supervisory Guideline of Foreign, Minority and International Schools." The data were analyzed by content analysis. Codes, categories, sub-themes and themes were formed primarily in the guideline and the related legal documents referred to after the preliminary examinations during the analysis of the data. Digitization of the data was also used to strengthen understanding in the transformation of the data into findings. Finally, the analysis was supported and interpreted with appropriate quotations according to the themes. Some of the statements in the guideline were evaluated separately under each theme since they were related to more than one theme due to the content in detail and the scope of the related article of the legal document referred to. Therefore, the related item was reused in every related theme while digitizing. The internal validity (credibility) of the data was ensured by expert review and colleague confirmation. For this purpose, the researchers, who examined the supervisory guidelines of different institutions, came together on a specific day and time every week via live meeting tools on the internet. The researchers analysed the content of the guidelines they examined, created codes and themes and focused on their similar and different aspects. Also, an academician and an inspector took part in these meetings to get their opinions and gave feedback during the meetings. Besides, the raw data of the research was stored for external reliability (confirmability). 
Findings: The guideline was related to literature and laws. This relationship was half-consistent and inconsistent based on both categories (literature and laws). Some of the legal documents referred to were not up to date or were repealed. Besides, there was no reference to the related legal document or a missing reference in some of the statements. Some of the legal documents referred to were not available on the internet. Besides, some of the statements were incomplete, inaccurate or more detailed according to the version in the legal document. Some statements had no legal basis since the legal document was repealed and a new one was not prepared. Besides, there were deficiencies in the content of some statements according to the literature. None of the statements was referred to scientific studies. The use of some of the concepts was inconsistent with the literature or some concepts covered each other. Finally, some expressions contradicted the literature and had to be corrected.

Suggestions: Practitioners may be offered to establish a unit for the preparation and updating of guidelines. Conferences or panels should be organized where inspectors can advise practitioners by discussing the content of guidelines and relevant legislation. Legal documents or attachments that are not available on the internet should be uploaded to the official website of the Inspection Board. Before preparing the supervisory guidelines, it may be suggested to examine the results and suggestions of scientific studies. On the other hand, researchers may conduct a study by interviewing some inspectors to identify the strengths and weaknesses of these guidelines. Also, they can develop a scale to determine the inspectors' level of performing supervision using the guidelines. It can be suggested to compare the guidelines with the ones prepared in foreign countries. Finally, it can be useful for researchers to choose one or more of these school types and examine their supervisory reports. 